Please do not remove this page

RMIT

UNIVERSITY

\title{
Cadbury and pig DNA: when issue management intersects with religion
}

Jaques, Tony

https://researchrepository.rmit.edu.au/esploro/outputs/9921860046801341/filesAndLinks?institution=61RMIT_INST\&index=null

Jaques, T. (2015). Cadbury and pig DNA: when issue management intersects with religion. Corporate Communications, 20(4), 468-482. https://doi.org/10.1108/CCIJ-10-2014-0066

Document Version: Accepted Manuscript

Published Version: https://doi.org/10.1108/CCIJ-10-2014-0066

Repository homepage: https://researchrepository.rmit.edu.au

(c) Emerald Group Publishing Limited

Downloaded On 2023/04/26 19:43:34 +1000

Please do not remove this page 
Thank you for downloading this document from the RMIT Research Repository.

The RMIT Research Repository is an open access database showcasing the research outputs of RMIT University researchers.

RMIT Research Repository: http://researchbank.rmit.edu.au/

\section{Citation:}

Jaques, T 2015, 'Cadbury and pig DNA: when issue management intersects with religion', Corporate Communications, vol. 20, no. 4, pp. 468-482

See this record in the RMIT Research Repository at:

https://researchbank.rmit.edu.au/view/rmit:33957

Version: Accepted Manuscript

Copyright Statement: (c) Emerald Group Publishing Limited

Link to Published Version:

https://dx.doi.org/10.1108/CCIJ-10-2014-0066 


\title{
Cadbury and pig DNA: When issue management intersects with religion
}

\section{Tony Jaques}

\author{
Citation: Corporate Communications: An International Journal, 20 (4) \\ 2015 pp 468-482
}

This is a final version submitted for publication.

Abstract

Minor editorial changes may have subsequently been made.

Purpose: This paper discusses the evolving role of religion in issue management and introduces a case in Malaysia to examine the emerging corporate risk when Western multinationals fall foul of the precepts of Islam.

Methodology: The paper details events when Cadbury in Malaysia faced online rumours that its locally-made chocolate was contaminated by porcine DNA and examines the corporate and community response in the context of issue management, international public relations, crosscultural communication theory and apologia theory.

Findings: The case illustrates that for a multinational company doing business in a Muslim country, an issue response strategy must be based on sound local knowledge and understanding of the religious implications.

Practical implications: Although issues in the public arena frequently have a political and legal dimension, a religious element can make issue management even more challenging. Internationalization of both business and issues has increased the profile of Islamic values, and the case shows the practical effectiveness of a calm and considered response in the face of extreme provocation.

Originality/Value: While Western public relations literature has highlighted cases of strongly held familiar Christian values driving issues onto the national issue management agenda, this paper identifies how Islamic precepts now represent an increasingly important consideration for modern risk and issue managers.

Keywords: Issues, religion, Islam, risk communication, food safety, halal

Paper type: Case study

\section{Introduction}

While issues in the public arena frequently have a political and legal dimension, sometimes a religious element also prevails and makes issue management even more challenging. Although Western public relations literature has highlighted case studies of strongly held Christian values driving issues onto the national agenda (see for example Jaques , 2013; Severson, 2012), more instances are now emerging where major Western multinationals fall foul of the precepts of Islam. 
This paper discusses the role of religion in issue management and introduces an incident in mid-2014 when Cadbury in Malaysia faced online rumours that its locally-made chocolate was contaminated by porcine DNA - a very damaging allegation in a largely Muslim nation where pigs are regarded as unclean and halal standards of food production are central to Islamic dietary practice.

Concerns about the halal (permissible) status of food are not uncommon, particularly in relation to multinational food and beverage companies (see for example McDonalds at http://islamnewsroom.com/news-we-need/36-is-mcdonalds-halal and Coca Cola at http://www.coca-cola.co.uk/faq/ingredients/is-coke-halal.html ). Yet few such concerns have received the media attention and international profile of the Cadbury case. Nor do they typically generate such an intense level of anger.

Using contemporary frameworks, including the 'Circuit of Culture' (Curtin and Gaither 2007) and apologia theory (Hearit, 1995), the case examines the emerging corporate risk for Western companies doing business in Muslim markets, and provides some valuable lessons for how a company can respond when caught up in an issue driven by politics and religious beliefs.

\section{Background}

When issue management was launched in 1976 and began to flourish in the early 1980s, it was unambiguously seen as a corporate activity designed to enable private sector business to establish a more level playing field with government and activists in the formulation of public policy.

The corporate approach was expressed by Howard Chase - the 'father' of the discipline - who described issue management as

the capacity to understand, mobilise, coordinate and direct all strategic and policy planning functions, and all public affairs/public relations skills, toward achievement of one objective: meaningful participation in creation of public policy that affects personal and organisational destiny (Chase, 1982, p 1)

However, over time the focus of issue management expanded beyond just public policy and began to assume a much broader application as its tools and techniques were adopted by governments and by community groups and NGOs, including many religious groups.

This more modern approach has led to issue management being defined as:

A coordinated cross-functional effort to identify, prioritise and actively manage towards resolution those developments that most impact the organisation and where there is a capacity to make a difference

Recognising this evolution, a current definition of an issue (updated from an early version developed by the New York-based Conference Board (Brown, 1979) is:

Any trend or development- real or perceived-usually at least partly in the public arena, which, if it continues, could have a significant impact on the organisation's financial position, operations, reputation or future interests and requires a structured response 
Beyond basic definitions, the characteristics of issues are also very important, particularly in the context of this paper. Some core characteristics of typical issues are that they involve external parties; have no black and white answer; may involve public policy or regulation; happen in public or in the news media; and emotions rather than data often prevail.

However the link between issue management and religion is further reinforced by one additional common characteristic of issues - namely that they often have a moral or ethical dimension.

While a moral or ethical dimension does not necessarily imply a specific religious context, it has fuelled many of the high-profile issues formulated or driven by the interests of various churches or religious beliefs.

This is not new, and the role of high-profile church leaders in championing public issues has a long history, going back well before issue management, including General William Booth (1824-1912) the founder of the Salvation Army, who exposed the plight of Britain's poor; Rev Dr Martin Luther King (1929-1968) who led the civil rights movement in the United States; and Bishop Desmond Tutu (b 1931) who fought against apartheid in South Africa.

But the broader participation of organized religion is more recent, as church and religious groups join with secular NGOs in utilizing the tools and techniques of issue management and harnessing the power of digital media to elevate issues onto the social and political agenda.

Individual religious leaders or organized churches have traditionally played a prominent role in humanist concerns, such as the anti-slavery campaign, the peace movement, the campaign against nuclear weapons or protesting against perceived erosion of minority rights. At the same time some groups and denominations have taken a very active role in driving particular issues, based on specific religious beliefs.

For example the Catholic church has mounted a systematic campaign of issue management and public relations in relation to embryonic stem cell research (Skene and Parker, 2002; Lynch et al, 2014), while Catholic and other religious groups have used conventional issue techniques to shape the abortion issue (Olavsky, 1989; Rohlinger, 2002). Similarly Christian churches, particularly in the United States and Britain, used their influence to drive a prolonged international boycott against Nestle and others in support of the contentious issue involving the promotion of baby formula in developing countries (Newton, 1999)

Religious groups have also become very active in some environmental issues, motivated by a belief that environmental degradation is "sacrilegious, sinful and an offence against God" (Gottlieb, 2006). This may take the form of a social initiative in support of an environmental objective, such as the USbased 'What would Jesus drive' campaign organized by the Evangelical Environmental Network to encourage a 'Christian decision' in buying a motor vehicle which will minimise waste and pollution "because transportation is a moral issue" ( www.whatwouldjesusdrive.info/).

At a more political level, religious involvement in an environmental issue was seen, for example, in the much-studied case of the Brent Spar, when Greenpeace in Britain and Germany campaigned to prevent disposal of a redundant oil storage buoy in the North Atlantic (Grolin, 1998). In Germany, Greenpeace enlisted the powerful Lutheran Church to support a national boycott against Shell. As one newspaper reported: "church leaders on Sunday endorsed a boycott of the oil company before 
80,000 cheering faithful in a Hamburg sports stadium" (Atkinson, 1995). The boycott was effective in Germany, Holland and parts of Scandinavia and, with falling sales and share price, Shell abandoned the planned deep-sea disposal.

The Brent Spar case exemplifies some of the broader challenges of cross cultural communication and managing issues across borders. This field has attracted very extensive scholarship, including more recently Bardhan and Weaver (2010), Freitag and Stokes (2008) and Neuliep (2012), as well as the wide-ranging writings of Sriramesh and Verčič (2003).

Curtin and Gaither (2007) argue that much of the cross-cultural communication literature takes an ethnocentric view and attempts to fit the Western approach to public relations onto other countries and cultures. However, they conclude that there is 'scant evidence' that standardised public relations approaches work across varied socio-economic, political and cultural systems. These scholars (Curtin \& Gaither 2005, 2007 and Gaither \& Curtin, 2008) have expanded the earlier idea of the Circuit of Culture into a more comprehensive cultural-economic model which places culture squarely at the centre of public relations practice and can provide new understanding of the function and role of public relations in international society.

Rather than focusing on the cultural indices championed by Hofstede (2001) - and their occasional association with unhelpful stereotypes - the Circuit of Culture approach provides guidance to practitioners negotiating issues of identity in an increasingly globalised world (Gaither and Curtin 2008) which, for the present discussion, leads directly to consideration of religion as a central factor.

It has long been recognised that "from a standpoint of the public affairs and government relations professional, public opinion about religion has strategic and ethical implications for issue management" (Badaracco, 1992, p 31). In the Western literature, that focus has for some time been mainly on the implications for issue management of Christian religious groups and broader 'Christian values.'

In more recent years, increasing attention has focused on cases where the teachings of Islam have been instrumental in elevating issues onto the international agenda.

\section{Conflict with Islam}

Al-Hyari et al (2011) developed a conceptual model to explore the link between religious beliefs and consumer behaviour, and concluded that "as a result of the increasing gap and cultural conflict between the Western and Muslim worlds, many international companies are negatively affected by changes in the international environment, which is reflected in consumer behaviour. This is particularly highlighted when these events are related to religious issues" ( $p 155$ ).

Their important study found a strong relationship and clear link between religiosity in Arabic/Islamic collectivist cultures and consumer behaviour, mainly boycotting.

The application of this link underlies particular issue management cases involving Islam, which highlight the potential impact for international business.

One of the highest profile cases of a Western company being caught up in an issue involving Islam occurred in late 2005 after the Danish newspaper Jyllands-Posten published offensive cartoons 
portraying the prophet Muhammad, causing predictable outrage throughout the Islamic world (Frandsen \& Johansen, 2010; Gaweesh, 2012, Maamoun \& Aggarwal, 2008).

Incensed by the Danish government's refusal to sanction the newspaper-citing the cause of free speech- early in 2006 Muslim leaders launched a boycott of Danish companies including dairy giant Arla, which had a major business presence in the Middle East. As a result, Arla's products disappeared off the shelves of 50,000 supermarkets across the Middle East; regional sales dropped from $\$ 1.8$ million daily to basically nothing in just five days; and the company was forced to shut down its cheese processing plant in Saudi Arabia and lay off staff in Denmark (Gaither \& Curtin, 2008).

Despite coming under severe criticism at home for 'cowing to fundamentalism', Arla (a DanishSwedish farmer-owned cooperative) began a strategy to distance itself from the cartoons in order to protect its important Middle Eastern market. The company also sponsored humanitarian projects in the Middle East (giving aid to disabled children, cancer sufferers and the hungry) and other activities that would build mutual understanding between different cultures. The boycott began to slowly turn around (Holmström, Falkheimer \& Nielsen, 2010), and two years later Arla announced that it had recovered 95 per cent of its previous sales in the Middle East (Flexnews, 2008).

Astrid Gade Nielsen, Arla's Corporate Communication Director at the time, later said that until the cartoon crisis, they had not fully understood what it really meant to be a truly global company. "It has changed our communication policy in the sense that we are very much more aware of how we communicate in a global community" (Nielsen, 2008, p. 63).

Central to the Arla case was the question of apologies, and their cultural sensitivity on both sides of the issue. Moslem leaders in the Middle East were particularly incensed by the refusal of the Danish government to apologise or to sanction the offending newspaper. Ambassadors of Muslim countries asked Danish Prime Minister Anders Fogh Rasmussen to take action, but his response was: "The Danish government cannot apologise on behalf of a Danish newspaper... Independent media are not edited by the government" (BBC World News, 2006). From an Arab perspective, though, freedom of expression does not mean freedom to insult (Maamoun \& Aggarwal, 2008).

Only then was the boycott was launched. Although the newspaper initially also refused to apologise, it eventually did so, and copies of that apology were widely circulated by Arla as part of its recovery strategy. However, because Arla itself had chosen to apologise, and lobbied the Prime Minster to do the same, the company faced a threatened boycott at home by Danes who perceived Arla's action as a denial of freedom of speech in Denmark (BBC World News, 2006).

In his seminal writings on apologia theory, Hearit $(1994,1995)$ emphasises that an apologia is not just an apology, although it may contain one. Rather that it is a defence which seeks to present a compelling counter-description of organisation actions. He says it functions to situate alleged organisation wrongdoing in a more favourable context than the initial charges suggest (Hearit, 1994, p 115). In this case Arla had done nothing wrong, yet the company implemented all three of Hearit's communicative strategies - persuasive accounts (to present a persuasive and plausible alternative narrative); statement of regret (to diffuse anger and hostility); and dissociation (to remove the association between the organisation and the wrongdoing). (Regester and Larkin, 2008, pp 60-62)

A less well known earlier case arose when Nike produced a new range of footwear, which featured a logo on the heel and sole that incorporated the word 'Air' in a design intended to represent flickering flames or heat rising from the pavement. But some Muslim critics claimed the logo could be 
interpreted as the word 'Allah' in Arabic script (Nike, 1997). Compounding their concern, shoes are considered unclean in Islam and are such an offensive symbol that it is seen as culturally unacceptable to cross an ankle over a knee and display the sole of the shoe while talking to another person.

Nike reportedly received independent advice from respected Islamic scholars that critics had misinterpreted the logo. Nevertheless the company apparently decided this was a cross-cultural debate it could not ' $w i n$ ' and recalled more than 30,000 pairs of the offending shoes and reassigned distribution of the remainder (Jury, 1997). They also agreed to build several playgrounds in Muslim communities as part of their apologia (Jury, 1997).

In the case of Nike, the company fully followed Hearit's first two strategies - persuasive accounts and statements of regret - and in the third category pursued one of the three forms of what Hearit calls appearance/reality bifurcations, specifically act/essence dissociation. This is when the organisation admits the act, but asserts that it is not representative of its essence or true nature. In other words, that the act is in no way reflective of how the organisation generally does business.

Like Arla, Nike was attacked by some critics for yielding to criticism. However the company took a business decision which recognised the cultural reality, and averted the threat of a global boycott. And like Arla, Nike said it had learned from the case. Spokesman Roy Agostino said they had introduced a review panel to prevent any similar problems in future. "We have, through this process, developed a deeper understanding of Islamic concerns and Islamic issues," he said. "As our brand continues to expand, we have to deepen our awareness of other world communities" (Jury, 1997).

The Nike case has particular relevance here because it revolves around differing Islamic perspectives, which is central to the case of Cadbury in Malaysia.

\section{Malaysia and Islam}

While Malaysia is a pro-business, multi-party democracy, with a secular legal system based on English common law (Malaysia gained independence from Britain in 1963), Islam and the state are inextricably intertwined. Moslems, who comprise more than two thirds of the population, are subject to sharia law in matters concerning their religion, and the political and social systems are heavily influenced by Islam (Peletz, 2002).

Typical of the new theocratic bureaucracy is the powerful Department of Islamic Development (JAKIM) which was created in 1997 to "protect the purity of faith and the teachings of Islam" (JAKIM, 2014). As a central government agency its purpose is to streamline and standardise Islamic law; to oversee administration of Islamic affairs at Federal and State level; and to develop Islamic education (JAKIM, 2014). Importantly for the present discussion, one of its specific tasks is to ensure compliance of products and services with the regulatory requirements of halal, which means permissible to Muslims. This is a critical role as halal food is a rapidly growing market and Malaysia has set itself the goal of being the "halal hub" for this global business (Othman et al 2009). JAKIM and its responsibility to provide halal-certification plays a key role in the case study which follows.

Another important aspect of the political-economic system in Malaysia is the heavy involvement of Government-controlled companies in many key industries. In this respect Cadbury Malaysia is a typical entity. The majority shareholder (at just under $40 \%$ ) is the global snack maker Mondelez 
International, with other shares held by two Malaysian Government-controlled companies (Mondelez International, 2014). It employs more than 1,600 people in Malaysia and has been making chocolate locally for more than 40 years (Diss, 2015).

\section{Cadbury and pig DNA}

In February 2014 routine tests by Malaysia's Ministry of Health found porcine (pig) DNA in two locally-made Cadbury products - Dairy Milk Hazelnut and Dairy Milk Roasted Almond (Kok Blok, 2014).

In late May a copy of the report was unofficially posted on social media sites and rumours began to spread in Malaysia, particularly on Facebook, that Cadbury chocolate may not be halal (see chronology table).

In line with the basic processes of issue management, Cadbury promptly stated on its Facebook page that it was aware of the rumour and stressed its position that all locally-made products are halalcertified by JAKIM.

"Care is taken with all the ingredients and production process," the company wrote. "We follow rigorous processes in making our chocolate to maintain our certification" (Cadbury, 2014a).

Immediately, the issue triggered hundreds of responses, overwhelmingly negative. The following day the Health Ministry confirmed that two samples tested were positive for porcine DNA. JAKIM suspended the halal certificate for the two products and Cadbury immediately withdrew them both.

On their Facebook page, in both English and Malay, Cadbury identified the batches which had been recalled and emphasised that no other products were affected.

We are undertaking a full review of the supply chain to ensure all quality standards continue to be met. We would like to reassure our consumers that all Cadbury chocolates manufactured in Malaysia are halal-certified by JAKIM, which includes the locations and raw materials used in the production of these products .... Thank you for your continued support (Cadbury, 2014b).

The official confirmation and recall announcement saw the company Facebook page, and other social media in Malaysia, light up with a fresh outburst of adverse comment. A common theme was to attack the perceived lack of an apology, and hundreds of online protesters poured out their criticism of the company, many vowing never again to buy Cadbury products.

With effective issue management requiring ongoing engagement, next day Cadbury posted a further message on their Facebook page: "We at Cadbury Malaysia understand that our customers are disappointed to hear the news of the recent test by the Ministry of Health on two of our products. We hear you and we value your comments and feedback over this issue" (Cadbury 2014c).

The company could hardly fail to hear the storm of comments, but at this stage the story was largely confined to social media and domestic news outlets. That situation abruptly changed a few days later with a remarkable news conference held by more than 20 Malay-Muslim NGOs on Tuesday 27 May, 2014 , which dramatically raised the public profile of the issue and generated international attention. 
At the news conference, the NGO leaders accused Cadbury of attempting to 'weaken' Muslims in Malaysia, and called for a national boycott and Jihad (holy war) against the company (Tan, 2014).

The tone of the meeting is typified by Abu Bakar Yahya, head of the organisation Perkasa Selamgor, who told reporters: "They have betrayed us Muslims by putting haram (forbidden) elements through the foods we consume in our body to weaken us. That is why Muslims are weak, divided" (Kamal 2014).

Ustaz Masridzi Sat, President of the NGO Perkid, said most social ill and cases of apostasy in Malaysia involving Muslims stemmed from them consuming food which was not halal. "Because the person eats pork it is difficult to guide him to the right path," said Mr Masridzi. "When the day of judgement comes, that person will be wearing a pig face because of what he has eaten" (Kamal 2014).

Another NGO leader called for the Cadbury factory in Malaysia to be shut down. "Muslims nationwide must boycott all their products," he said. "We have the power to take down this giant" (Kamal, 2014). Other critics were reported going even further, suggesting that the Cadbury factory should be burned down, and that people who had eaten the chocolate should demand a blood transfusion (Darwis, 2014).

Speaking for mainstream Islam, even the Grand Imam of the National Mosque in Kuala Lumpur called for a hefty fine and shutdown of the Cadbury Malaysia plant "to serve as a lesson for other food producers to ensure their product is halal" (The Guardian, 2014).

Against such views, contrary voices were hard to find. Dr Mohd Asri Zainul Abidin, a professor of Islamic Studies and a widely-published authority on Islam in Malaysia, said that while consumers had a right to protest if they felt they had been misled, there was no reason to call for a jihad, and noone had been forced to buy Cadbury products. He said some of the views expressed were extreme and did not represent Islam and added that, while the consumption of pork is forbidden in Islam, if it is "consumed in innocence, without foreknowledge, then that person has not sinned" (Tan, 2014).

Similarly, the Malaysian Islamic Youth Movement (ABIM) dismissed the call to burn Cadbury factories as being "extremist and un-Islamic" (Coconuts KL, 2014).

However, calls for restraint did little to slow the issue, which now gained international attention and raised issues about Cadbury in other countries. Indonesia - the world's most populous Muslim nation - announced tests of Cadbury products, even though the recalled products were not sold there (Channel News Asia, 2014a) and Saudi Arabia announced similar tests, even though its Cadbury products are made in Egypt and the United Kingdom (Thomas, 2014).

In addition Singapore, Malaysia's nearest neighbour, announced that while it did not import the two batches of Cadbury chocolate concerned, the Agri-Food \& Veterinary Authority would check similar products under the Cadbury brand available in Singapore to "ensure the ingredients used in the manufacturing of the products are truly as declared under the statement of ingredients" (Channel News Asia, 2014b).

Even in Britain, the corporate affairs spokesperson for Mondelez, which owns the Cadbury brand, felt it was necessary to provide reassurance that the contaminant had not affected that country. 
"The matter in Malaysia, has not affected the brand's ingredient integrity whatsoever in the UK" (Asian Express, 2014).

Meanwhile, in Malaysia, the issue was escalated further when the Malaysian Muslim Wholesalers and Retailers Association directed its 800 members not just to pull Cadbury products off the shelf, but also other brands from the Kraft Foods stable, of which Cadbury is one. This expanded list included household brands such as Jacob's, Oreo and Twisties (Naidu, 2014).

In the face of a mounting barrage of criticism, and with new test results still not known, Cadbury Malaysia's head of Corporate Affairs, Raja Zalina Raja Safran, issued a carefully considered strategic statement. It emphasised that Cadbury remained in close consultation with Malaysian authorities, and was meeting with stakeholders and leaders in the Muslim community to assure them of the company's commitment to halal regulatory guidelines, and commitment to the best testing practices for Malaysian consumers.

Although Cadbury proactively and voluntarily recalled the products, we have no reason to believe that there is any porcine or pork-related ingredient in our Cadbury chocolates. We stand by our halal certification and we have the highest levels of product labelling standards. ... We understand how critical halal is to our consumers and how important it is to the ongoing trust in our products. All other products in the Malaysian Cadbury range maintain their halal status (Safran, 2014)

Three days later came the news Cadbury was waiting for. The Government's top Islamic authority (JAKIM) announced that new tests had been done on 11 samples of hazelnut and roast almond chocolate products and none showed any traces of porcine contamination. One of the JAKIM officials went so far as to say he would happily eat the chocolate to prove it safe for Muslim consumption (BBC World News, 2014).

Cadbury Malaysia immediately launched an advertising blitz under the slogan "All is good. Enjoy us again." The advertisement declared: "Your Cadbury chocolate made and sold in Malaysia is certified halal. You've trusted us for 40 years and can continue to do so. Thank you Malaysia for believing in us" (Cadbury, 2014d). In a supporting statement Sunil Sethi, Managing Director of Mondelez Malaysia, said the new tests confirmed what the company had believed all along.

Having operated in Malaysia for over 40 years, nothing is more important to us than our consumers' trust. We intend to put this incident behind us and focus on spreading joy which is at the heart of everything we do at Cadbury. While incidents such as this are unfortunate, we are grateful to the relevant authorities for clearing up the air and ensuring that future abnormalities in their test results would be verified internally before making them public (Cadbury, 2014d).

\section{Summary Chronology}

\begin{tabular}{|l|l|}
\hline Thursday 27 February 2014 & $\begin{array}{l}\text { Malaysian Ministry of Health finds porcine DNA in two samples } \\
\text { of locally made Cadbury chocolate. Cadbury is not advised. }\end{array}$ \\
\hline Friday 23 May & $\begin{array}{l}\text { Report unofficially posted on social media and rumour spreads } \\
\text { that Cadbury chocolate may not be halal. Cadbury Malaysia says } \\
\text { it is aware of the rumour. }\end{array}$ \\
\hline Saturday 24 May & $\begin{array}{l}\text { Health Ministry confirms two samples tested positive for traces } \\
\text { of porcine DNA. Cadbury announces recall. }\end{array}$ \\
\hline
\end{tabular}




\begin{tabular}{|l|l|}
\hline Monday 26 May & $\begin{array}{l}\text { Singapore authorities say they will do checks on declared } \\
\text { ingredients in Cadbury products. }\end{array}$ \\
\hline Tuesday 27 May & $\begin{array}{l}\text { Press conference by 20 Malaysian Muslim groups severely } \\
\text { criticises Cadbury. Some call for a boycott or even a Jihad } \\
\text { against the company. }\end{array}$ \\
\hline Thursday 29 May & $\begin{array}{l}\text { Moderate Muslim leaders call for calm. Malaysian Muslim shop } \\
\text { owners association directs members to withdraw all Kraft food } \\
\text { products. }\end{array}$ \\
\hline Friday 30 May & $\begin{array}{l}\text { Cadbury restates its commitment to adhering to Malaysian halal } \\
\text { regulations. Indonesia announces product tests. }\end{array}$ \\
\hline Saturday 31 May & Saudi Arabia announces it will test product. \\
\hline Monday 2 June & Fresh test results show no traces of porcine contamination. \\
\hline Wednesday 4 June & $\begin{array}{l}\text { Cadbury says findings "clear the air" and launches advertising } \\
\text { campaign in Malaysia: "All is good. Enjoy us again." }\end{array}$ \\
\hline
\end{tabular}

\section{Aftermath}

Following the fresh tests, the Muslim Consumers Association of Malaysia announced it would maintain its call for a boycott of Cadbury until the Health Ministry acknowledged its original tests had been incorrect. But the Health Ministry said it had "handed the entire issue over to the Islamic agency" (BBC World News, 2014). The Health Ministry also said it was investigating the officer who leaked the preliminary report in the chocolates "which was released prematurely before the findings could be corroborated" (Channel News Asia, 2014c). At the same time the Malay-Muslim NGOs lodged a police complaint that conflicting reports had caused confusion among Muslim consumers in the country.

A Minister in the Prime Minister's Department, Datuk Seri Jamil Khir Baharom, was later reported saying the original tests by the Health Ministry could have been flawed as the samples were not brought in direct from Cadbury's factory. There was a possibility, he said, that the previous sample could have been 'contaminated' resulting in porcine DNA being detected (MalayMail, 2014).

\section{Discussion}

While Arla and Nike made explicit public apologies, Cadbury did not. Indeed the failure to provide such an apology was strongly criticised by some online commentators and members of the public. In retrospect it might have been helpful to apologise for consumer concern which the reports had created, although it could also be argued that any apology could have been seen as admitting liability on the company's part.

However, the question of when and whether to apologise in a crisis is a highly contentious area of scholarship, which has yet to yield firm consensus (see for example Coombs and Holladay, 2008; Coombs et al 2010, Hearit and Roberson 2009). Moreover there are acknowledged differences between the western and non-western approaches to this issue (see for example Hagiwara 2007; Inoue, 2010).

Furthermore, the Cadbury's actions did not align precisely with any of the classic image restoration strategies in the theoretical approach developed by Benoit (1995), including denial, evasion of responsibility, reducing offensiveness, corrective action and mortification. Here again, by Western standards, Cadbury's response could be characterised as overly passive. Yet it was both culturally 
and professionally effective and the case provides some valuable lessons for managing an issue where religion and politics threaten a multinational brand.

Perhaps most important was that Cadbury did not publicly dispute the more extreme religious interpretations promoted by some Malay-Muslim organizations. As a high-profile and brandsensitive corporation operating in a majority Muslim country, Cadbury seemingly recognised that there was no real upside in challenging the views of sectional leaders.

Cadbury stated on its Facebook page that it "valued comments and feedback" although some of the comment posted was undoubtedly inflammatory and extremely damaging. Yet the company appeared to resist the temptation to delete these more extreme views.

Similarly, it would have been tempting for Cadbury to seek out and encourage more restrained third party expert commentary. But there is no evidence of this in the publicly available material. A respected moderate religious authority spoke out, as did a Moslem youth organisation, but both appear to have done so in response to media inquiries.

Navigating through the volatile mix of race, religion and politics, Cadbury maintained a determinedly neutral position. They could have entered the debate - directly or indirectly - about the differing interpretations of halal and its implications for true Muslims, but clearly chose not to.

While this strategy may seem self-evident, other companies have suffered after 'taking sides' in a religious-based issue. A high-profile recent example is the 'family value' US fast-food company Chickfil-A which took a very public stance in 2012 against same-sex marriage. The result was a damaging controversy which resulted in prolonged impact on Chick-fil-A's reputation (Rhodan, 2014). As the company ruefully admitted at the time: "Going forward, our intent is to leave the policy debate over same-sex marriage to the government and political arena" (Chick-fil-A, 2012)

Another key response by Cadbury was not to publicly dispute the original Health Ministry test which reported the existence of porcine DNA. Both Nike and Cadbury had grounds to doubt the expressed view of religious leaders, but recognised the severe risks of publicly challenging those views. While Cadbury said later that they "believed all along" the product was not contaminated, and said test results needed better internal verification, the strategy not to challenge the Ministry testing was crucial. In reality Cadbury and the Government had a common interest in managing an activist Muslim public.

Even after the incident was over, demands continued for a fuller explanation about the analysis of Malaysian-made chocolate (Channel News Asia, 2014c), but Cadbury had seemingly concluded early on that publicly undermining the official testing laboratory was an unproductive course of action.

The danger of taking the alternative approach was starkly illustrated in 2006 after Chinese authorities reportedly detected heavy metals in SKII cosmetics imported from Japan (Tai, 2008). Brand-owner Proctor and Gamble challenged the findings and emphasised that tests in other countries cleared the products. However they learned to their reputational and commercial cost that Chinese consumers are much more inclined to give weight to Government testing authorities than the views of a foreign multinational.

Following this example, brand-owner Mondelez could have attempted to encourage a more proactive Western-style response by Cadbury in Malaysia. But in a country or market where religion and politics are intimately linked, corporations, especially from outside that culture, must implement specific strategies to recognise and respect the prevailing social norms. 
Here the multinational parent company appeared to deliberately endorse a low-key locally-managed response, reflecting local needs and sensitivities. As a result the incident was largely over in less than two weeks and product sales resumed.

In any case like this the need to protect the global brand is critical, and it is not uncommon to use an outside spokesperson for corporate messaging. However the response in Malaysia was left broadly to just two respected local spokespersons .

Overall, Cadbury used social media to sustain a regular and consistent flow of management communication which was calm, informative and respectful. When emotions were running high, and Cadbury found itself caught between widely differing interpretations of Islamic practice, the company steered an effective path which protected its brand and avoided inflaming an already volatile issue.

\section{References}

Al-Hyari, K., Alnsour, M., Al-Weshah, G. and Haffar, M. (2011), "Religious beliefs and consumer behaviour: from loyalty to boycotts", Journal of Islamic Marketing, Vol 3 No 2, pp 155-174.

Asian Express (2014), “Jihad against Cadbury”, 30 May. Retrieved from http://www.asianexpress.co.uk/2014/05/jihad-against-cadbury/ (accessed 16 July 2014)

Atkinson, R. (1995), "A Very Cautious Watch on the Rhine; Bosnia, Oil Rig Illustrate German Instinct to Follow Rather Than Lead on Major Issues", Washington Post, 22 June, p. A24.

Badaracco, C. (1992), "Religious lobbyists in the public square", Public Relations Quarterly, Vol 37 No 1, pp 30-36.

Bardhan, N, and Weaver, C. K. (2010), Public relations in global contexts: Multi-paradigmatic perspectives. Taylor and Francis, London,

BBC World News (2014), "Cadbury Chocolate pork free, says Malaysian Islamic body", 2 June. Retrieved from http://www.bbc.com/news/business-27663857 (accessed 14 June 2014)

BBC World News (2006), "Nordic firm hit by Arab boycott" 31 January. Retrieved from http://news.bbc.co.uk/2/hi/middle east/4666298.stm (accessed 22 December 2014)

Benoit, W. L. (1995), Accounts, excuses and apologies: A theory of image restoration strategies. State University Press of New York, Albany, NY.

Brown, J. K. (1979), This business of issues: Coping with the company's environments. The Conference Board, New York.

Cadbury (2014a), "We have been made aware of certain information being distributed on social media", Cadbury Malaysia Facebook page, 23 May. Retrieved from https://www.facebook.com/CadburyMalaysia/posts/729092663801008 (accessed 24 July 2014) Cadbury (2014b), "We at Cadbury would like to respond to the report", Cadbury Malaysia Facebook page, 24 May. Retrieved from https://www.facebook.com/CadburyMalaysia/posts/729333280443613) (accessed 24 July 2014) 
Cadbury (2014c), "We at Cadbury understand that customers are disappointed", Cadbury Malaysia Facebook page, 25 May. Retrieved from

(https://www.facebook.com/CadburyMalaysia/posts/729797883730486) (accessed 24 July 2014)

Cadbury (2014d), "Our chocolates are halal", Cadbury Malaysia Press statement, 3 June. Retrieved from http://www.cadbury.com.my/\#message (accessed 24 July 2014)

Channel News Asia (2014a), "Indonesia tests Cadbury products in pig DNA scare", 30 May. Retrieved from http://www.channelnewsasia.com/news/asiapacific/indonesia-tests-

cadbury/1130124.html (accessed 16 July 2014)

Channel News Asia (2014b), "No import of pig DNA-tainted Cadbury chocolate in Singapore", 26 May. Retrieved from http://www.channelnewsasia.com/news/singapore/no-import-of-pigdna/1122860.html (accessed 16 July 2014)

Channel News Asia (2014c), "Malaysian NGOs lodge police report in pig DNA controversy", 5 June. Retrieved from http://www.channelnewsasia.com/news/asiapacific/m-sian-ngos-lodgepolice/1137080.html (accessed 16 July, 2014)

Chase, W. H. (1982), "Issue Management Conference - A special report", Corporate Public Issues and their Management, Vol 7 No 23, pp 1-2.

Chick-fil-A (2012), "Chick-fil-A response to recent controversy", Chick-fil-A company statement. Retrieved from http://media.chick-fil-a.com/Media/PDF/LGBT-statement.pdf (accessed 28 July 2014)

Coconuts KL (2014), "National Fatwa Council says tainted Cadbury chocolates are halal after all', weblog post 30 May. Retrieved from http://kl.coconuts.co/2014/05/30/chocolategate-nationalfatwa-council-says-tainted-cadbury-chocolates-are-halal-after-all (accessed 1 December 2014)

Coombs, T. W. and Holladay, S. J. (2008), “Comparing apology to equivalent crisis response strategies: Clarifying apology's role and value in crisis communication", Public Relations Review, Vol 34, No 3, pp 252-257.

Coombs, T. W., Frandsen, F., Holladay, S. J., and Johansen, W. (2010), "Why a concern for apologia and crisis communication", Corporate Communication, Vol 15 No 4, pp 337-349.

Curtin, P. A. and Gaither, T. K. (2007), International Public Relations: Negotiating culture, identity and power. Sage, Thousand Oaks, CA.

Curtin, P. A. and Gaither, T. K. (2005), "Privileging identity, difference and power: the circuit of culture as a basis for public relations theory", Journal of Public Relations Research, Vol 17, No 2, pp 91-115.

Darwis, M. F. (2014), "Malay NGO to sue Cadbury for RM100 million over pig DNA found in chocolates," The Malaysian Insider (26 May). Retrieved from http://www.themalaysianinsider.com/malaysia/article/malay-ngo-to-sue-cadbury-over-discoveryof-pig-dna (accessed 22 December, 2014) 
Diss, F. (2015), "Mondelez Malaysia cultivates talent to transform snacking business", New Straits Times (23 March). Retrieved from http://www.nst.com.my/node/77250 (accessed 1 June 2015)

Flexnews (2008), "Arla's Middle East sales bounce back after cartoon crisis", 30 January. Retrieved from www.flex-news-food.com/console/PageViewer.aspx?page=13908 (accessed 22 October 2013)

Frandsen, F. and Johansen, W. (2010), "Crisis Communication, complexity and the cartoon affair: A case study", in Coombs, W. T and Holladay, S. J. (Eds.), The handbook of crisis communication. Wiley Blackwell, Malden, MA , pp. 425-448.

Freitag, A. R. and Stokes, A. Q. (2008), Global Public Relations: Spanning borders, spanning cultures. Taylor and Francis, London.

Gaither, T. K. and Curtin, P.A. (2008), "Examining the heuristic value of models of international public relations practice: A case study of the Arla Foods crisis", Journal of Public Relations Research, Vol 20 No 1, pp 115-137.

Gaweesh, K. S. (2012), "Corporate reputation and communication: The case of Arla Foods and Prophet Muhammad cartoons", Journal of Arab and Muslim Media Research, Vol 5 No 3, pp 259-277.

Gottlieb, Roger S. (2006), A Green Faith: Religious Environmentalism and Our Planet's Future. Oxford University Press, Oxford, UK.

Grolin, J. (1998), "Corporate Legitimacy in Risk Society: The Case of Brent Spar", Business Strategy and the Environment, Vol 7 No 4, pp 213-222.

Hagiwara, T. (2007), "The Eight Characteristics of Japanese Crisis-Prone Organizations", In C. M. Pearson, C. Roux-Dufort \& J. A. Clair (Eds.), International Handbook of Organizational Crisis Management (pp. 253-270), Sage, Thousand Oaks, CA.

Hearit, K. M. (1995), “'Mistakes were made': Organisations, apologia and crises of social legitimacy”, Communication Studies, Vol 46 No 1/2, pp 1-17.

Hearit, K. M. (1994), "Apologies and public relations crises at Chrysler, Toshiba and Volvo", Public Relations Review, Vol 20 No 2, pp 113-125

Hearit, K. M., \& Roberson, K. M. (2009), "Denial, Differentiation and Apology: on the use of apologia in crisis management" In R. L. Heath \& H. D. O'Hair (Eds.), Handbook of Risk and Crisis

Communication. (pp 542-559) New York: Routledge.

Hofstede, G. (2001), Culture's consequences: Comparing values, behaviors, institutions and organisations across nations ( $2^{\text {nd }}$ edtn). Sage, Thousand Oaks, CA.

Holmström, S., Falkheimer, J. and Nielsen, A. G. (2010), "Legitimacy and strategic communication in globalisation: The cartoon crisis and other legitimacy conflicts", International Journal of Strategic Communication, Vol 4 No 1, pp 1-18.

Inoue, T. (2010, 24 May), "A culture of Apologies: Communicating crises in Japan", Public Relations Strategist. Retrieved 
from http://www.prsa.org/Intelligence/TheStrategist/Articles/view/8644/1013/A culture of apolog ies Communicating crises in Jap (accessed 1 June 2015)

JAKIM (2014). About JAKIM, Department of Islamic Development. Retrieved from http://www.islam.gov.my/en/about-jakim (accessed 22 December 2014)

Jaques, T. (2013). "Ensnared in a gay health controversy: A comparative study in responding to issue activism", Journal of Public Affairs, Vol 13 No 1, pp 53-60.

Jury, L. (1997), "Nike to trash trainers that offended Islam", The Independent, 25 June. Retrieved from www.independent.co.uk/news/nike-to-trash-trainers-that-offended-islam-1257776.html (accessed 4 October 2013)

Kamal, S. M. (2014), "Muslim groups declare 'jihad' on Cadbury: claim wider agenda to weaken faith", MalayMail, 27 May. Retrieved from http://www.themalaymailonline.com/malaysia/article/muslimgroups-declare-jihad-on-cadbury-claims-wider-agenda-to-weaken-faith (accessed 14 June 2014)

Kok blok (2014), The Malaysian Pork Choc Controversy, weblog post, 27 May. Retrieved from http://k0ks3nw4i.blogspot.com.au/2014/05/the-malaysian-pork-choc-controversy.html (accessed 14 June 2014)

Lynch, J., Bennett, D., Luntz, A., Toy, C. and VanBenschoten, E. (2014), "Bridging Science and Journalism: Identifying the Role of Public Relations in the Construction and Circulation of Stem Cell Research Among Laypeople", Science Communication, Vol 36 No 4, pp 479-501

Maamoun, A. and Aggarwal, P. (2008), "Guilty by association: the boycotting of Danish products in the Middle East", Journal of Business Case Studies, Vol. 4 No. 10, pp. 35-42.

MalayMail (2014), "Health Ministry to work closely with JAKIM after Cadbury saga", 3 June. Retrieved from http://www.themalaymailonline.com/malaysia/article/health-ministry-to-workclosely-with-jakim-after-cadbury-saga\#sthash.hg3vPmUm.dpuf (accessed 16 July 2014)

Mondelez International (2014), Fact Sheet 2014, Mondelez International. Retrievved from http://www.mondelezinternational.com/ /media/mondelezcorporate/Uploads/downloads/mo ndelez intl fact sheet.pdf (accessed 11 December 2014)

Naidu, S. (2014), "Malaysia's pig DNA controversy spreads beyond Cadbury", Channel News Asia, 29 May. Retrieved from http://www.channelnewsasia.com/news/asiapacific/malaysia-s-pigdna/1127598.html (accessed 10 June 2014)

Neuliep, J. W. (2012), Intercultural communication: A contextual approach (5 $5^{\text {th }}$ Edtn). Sage, Thousand Oaks, CA.

Newton, L. H (1999), "Truth is the Daughter of Time: The Real Story of the Nestle Case", Business and Society Review, Vol 104 No 4, pp 367-395.

Nielsen, A. G. (2008). "We had to set things straight", Communication Director, No 1, pp 60-63.

Nike (1997), "Nike reaches accord with Islamic Group CAIR", Nike press statement, 24 June. Retrieved from http://www.thefreelibrary.com/NIKE+Reaches+Accord+With+Islamic+Group+-+CAIR-a019528345 (accessed 21 July 2014) 
Olavksy, M. (1989), "Engineering Social Change: Triumphs of Abortion Public Relations from the Thirties through the Sixties", Public Relations Quarterly, Vol 33 No 4, pp 17-21.

Othman, P, Sungkar, I, and Hussin, W.S.W. (2009), "Malaysia as an international halal food hub: Competitiveness and potential of meat-based industries", ASEAN Economic Bulletin, vol. 26, no. 3, pp. 306-320.

Peletz, M. G. (2002). Islamic modern: Religious courts and cultural politics in Malaysia, Princeton University Press, Princeton, NJ.

Regester, M. and Larkin, J. (2008), "Risk issues and crisis management: A casebook of best practice" $\left(4^{\text {th }}\right.$ Edtn), Kogan Page, London.

Rhodan, M. (2014), Chick-fil-A CEO regrets same-sex marriage debacle", Time Magazine, 17 March. Retrieved from http://time.com/27940/chick-fil-a-dan-cathy-gay-marriage/(accessed 28 July 2014)

Rohlinger D. A. (2002), "Framing the abortion debate: Organizational Resources, Media Strategies, and Movement-Countermovement Dynamics", The Sociological Quarterly, Vol 43 No 4, pp 479-507.

Safran, R. Z. R. (2014), "Cadbury Confident Chocolates halal”, Cadbury corporate statement, Malaymail, 30 May. Retrieved from http://www.themalaymailonline.com/what-youthink/article/cadbury-confident-chocolates-halal-raja-zalina-raja-safran (accessed 27 July 2014)

Severson, K. (2012). "Chick-fil-A thrust back into the spotlight on gay rights", New York Times, 25 July. Retrieved from http://www.nytimes.com/2012/07/26/us/gay-rights-uproar-over-chick-fil-awidens.html? $r=0$ (accessed 26 September, 2014).

Skene, L. and Parker, M. (2002), "The role of the church in developing the law", Journal of Medical Ethics, Vol 28 No 4, pp 215-218.

Sriramesh, K. and Verčič, D. (2003) (Eds), The global public relations handbook: Theory, research, and practice. Lawrence Erlbaum Associates, Mahwah, NJ.

Tai, S. H. C. (2008), "Beauty and the Beast: The Brand Crisis of SK-II Cosmetics in China", Asian Case Research Journal, Vol 12 No 1, pp 57-71.

Tan, E. (2014), “'Jihad' declared against Cadbury. What should the brand do?”, PR Week (Asia), 29 May. Retrieved from http://www.prweek.com/article/1296417/jihad-declared-against-cadburybrand-do (accessed 4 July 2014)

The Guardian (2014), "Pork in Cadbury's: Malaysian Chocolate recalled after DNA traces found" 28 May. Retrieved from http://www.theguardian.com/business/2014/may/28/pork-in-cadburysmalaysian-chocolate-recalled-after-dna-traces-found (accessed 1 December 2014)

Thomas, B. (2014), "Saudi tests Cadbury chocolates after pig DNA detected in Malaysia products", Arabian Business, 1 June. Retrieved from http://www.arabianbusiness.com/saudi-tests-cadburychocolates-after-pig-dna-detected-in-malaysia-products-552283.html (accessed 16 July 2014) 
